\title{
Public management, policy capacity, innovation and development
}

ERKKI KARO

RAINER KATTEL*

In this paper we discuss the question of what factors in development policy create specific forms of policy capacity and under what circumstances developmentoriented complementarities or mismatches between the public and private sectors emerge. We argue that specific forms of policy capacity emerge from three interlinked policy choices, each fundamentally evolutionary in nature: policy choices on understanding the nature and sources of technical change and innovation; on the ways of financing economic growth, in particular technical change; and on the nature of public management to deliver and implement both previous sets of policy choices. Thus, policy capacity is not so much a continuum of abilities (from less to more), but rather a variety of modes of making policy that originate from co-evolutionary processes in capitalist development. To illustrate, we briefly reflect upon how the East Asian developmental states of the 1960s-1980s and Eastern European transition policies since the 1990s led to almost opposite institutional systems for financing, designing and managing development strategies, and how this led, through co-evolutionary processes, to different forms of policy capacity.

Keywords: innovation; economic development; economic planning; political economy; transition economies.

JEL Classification: O25; P110: P160; P520.

\footnotetext{
"Research Fellow at Ragnar Nurkse School of Innovation and Governance, Tallinn University of Technology (Estonia). E-mail: erkki.karo@ttu.ee; Professor at Ragnar Nurkse School of Innovation and Governance, Tallinn University of Technology (Estonia). E-mail: rainer.kattel@ttu.ee. Research for this article was partially supported by the Estonian Science Foundation (grants no 8418 and 9404) and by the European Social Foundation through the Research and Innovation Policy Monitoring Programme. Submitted: 12/April/2013: Approved; 28/May/2013.
} 
Administration is the most obvious part of Government; it is Government in action; it is the executive, the operative, the most visible side of Government, and is of course as old as Government itself. It is Government in action, and one might very naturally expect to find that Government in action had arrested the attention and provoked the scrutiny of writers of politics very early in the history of systematic thought. But such was not the case.

Woodrow Wilson, (1887) The Study of Administration.

\section{INTRODUCTION}

Policy capacity - simply understood as "the ability to marshal the necessary resources to make intelligent collective choices and set strategic directions for the allocation of scarce resource to public ends" (Painter \& Pierre, 2005, p. 2) - is in many ways the holy grail of economic growth and development. ${ }^{1}$ Both mainstream and heterodox theorists of development agree that having policy capacity holds the key to solving many developmental challenges, especially if policy capacity is understood to include abilities to maneuver international policy waters and power relations (Jayasuriya, 2005). When policy capacity is seen to be the key, then technological change and innovation are widely acknowledged to be the locks that need to be unlocked for development and economic growth. Thus, policy capacity is about the ability to design and carry out national industrial and/or innovation policies and strategies that bring about economic development. However, in most debates that touch upon development policy, creating policy capacity is seen as a rather straightforward task that is dependent on the given forms of institutional context. Or, we can talk about policy bias: development discussions are mostly substantial and the 'what' is more important than the 'how'. For instance, debates are about whether tariff policies are good or not for industry and innovation, not about how we design and implement such policies; debates are about subsidies vs loans for firms dealing with R\&D, not which public organization administers such programs and how. Such bias often leads to simplified and generic views of policy implementation that disregards the evolutionary dynamics in the ideas and models of policy implementation (Karo, 2012).

However, we contend that strictly speaking there is no such thing as policy -

\footnotetext{
${ }^{1}$ In what follows we use policy capacity as a concept as it is used in public administration/management and public policy literature, referring to meso- and micro-level processes of public policy making, exemplified in the quote starting this paper and explained in detail in the first section of the article, and not in a much wider and abstract sense often used in mainstream institutional literature following Douglass North (1990) and others (i.e., looking at policy capacity as a factor on the macro-level political deliberations between actors - executive, legislative etc. - where institutions of public policy implementation enter into the equation only occasionally and as tools of political deliberations).
} 
policies exist, that is they become reality, only through their implementation. Implementation means concrete people in a concrete organization with their values, legal and power basis, coalitions and interactions with other public- and private-sector organizations. These public-sector organizations - the part of the public sector that we can call public management - have their rules how they recruit and promote people, how they understand their own, and others' performance and accountability, indeed their entire set of tasks. Further, as concrete people, managers and civil servants are the ones implementing policy, and they are the ones having contact with the subjects of a given policy - in case of economic and technology policy, private companies mostly, but also universities, labor unions, industry associations, etc. So, often implementation becomes crucial for what the given policy is and does. Because of learning and feedback mechanisms between civil servants and private-sector actors, entrepreneurs and others actors in the policy-implementation phases, implementation also becomes key for how the given policy is evaluated, and changed if needed. The realization of policy ideas through implementation is conditioned by different factors from culture to geography to time. Thus, it is impossible to understand policy capacity (or policy effectiveness, or performance), how it is generated, maintained and changed, without public management; in order to understand policy capacity we have to speak about the co-evolutionary processes between political and policy ideas, public management or implementation, and private-sector dynamism.

In our opinion the literature on economic development has so far not tried to deliver a systematic framework to understand how and why public-sector capacities and in particular policy capacities change and co-evolve with other variables in the capitalist systems. The developmental state literature is probably the most important attempt at introducing public management as one of the key explanatory factors of economic development and dynamism. Studies by Johnson (1982), Wade (1990), Amsden (1989), Evans (1995), to name but the best-known cases, have offered key historical insights on how bureaucracies - or Weberian public management structures that rely on merit-based career systems and clearly established administrative procedures - have been fundamental to East Asian developmental states. Yet, there is no explicit attempt in these studies to theoretically explain how and why these Weberian elements managed to create policy capacity within Government bureaucracies in a way that was supportive of development in the private sector, and how capabilities evolving in the private sector influence in turn the evolution of bureaucracies (see also Haggard, 2004; Yeung, 2013; Underhill \& Zhang 2012). Rather, the existence of Weberian bureaucracy is seen as a historical and explanatory variable. ${ }^{2}$

In sum, there is a question that has not been asked in the economic development context and to which we wish to contribute with this paper: what factors in co-

\footnotetext{
${ }^{2}$ This criticism can be extended also to different types of varieties of capitalism literature (e.g., Bresser-Pereira, 2012; Dore, 2000; Hall \& Soskice, 2001; Hollingsworth \& Boyer, 1997; Lane \& Myant, 2007; Zysman, 1983; Walter \& Zhang, 2012; Whitley, 1999).
} 
evolutionary processes initiate and direct learning processes in public management; that is, how and why policy capacity evolves; and why under certain circumstances complementarities or mismatches between the public and private sectors emerge. Or, to use a concept introduced by Yeung (2013), why in certain period Governments strategically and successfully manage to couple efforts with private sector for economic development and in other periods the sectors remain de-coupled.

In what follows we assume that co-evolutionary processes are always taking place in capitalist development, yet these processes lead to varying socio-economic results; and that policy capacity exemplifies the nature of these co-evolutionary processes and their results; or, also poor development results from co-evolutionary processes. Thus, we intend to show that policy capacity is not so much a continuum of abilities (from less to more), but rather a variety of modes of making policy that originate from co-evolutionary processes in capitalist development.

In the next section we develop a co-evolutionary framework for understanding policy capacity in the context of development policy. Thereafter, we use this framework for a brief discussion of what kind of policy capacity was created by, and evolved in, specific co-evolutionary processes in two historically and regionally different cases - East Asian economies in the 1960s to the 1980s and Eastern European economies since the $1990 \mathrm{~s}$ - with almost diametrically different co-evolutionary processes and outcomes; or how political vision, public policies and their management and private-sector dynamism came together in these specific contexts. ${ }^{3}$

\section{CO-EVOLUTIONARY DEVELOPMENT PROCESSES AND POLICY CAPACITY}

\section{Unpacking policy capacity}

We build the analytical notion of policy capacity by distinguishing between different concepts that reveal the political, policy and administrative underpinnings of public policies (based on Painter \& Pierre, 2005, pp. 2-7; also Karo \& Kattel, 2010a). The broadest concept can be defined as state capacity, that is, achieving

\footnotetext{
${ }^{3}$ We discuss the East Asian developmental state and Eastern European transition period as these allow us to reveal the diversity of co-evolutionary processes and outcomes forming policy capacity. This discussion is meant to be illustrative of this diversity and not intended to provide new explanatory models or disregard existing ones. Looking at two different regions starting its' development processes in two different development policy 'paradigms' (developmental state $v s$ Washington Consensus) allows us to illustrate the co-evolutionary dynamics during each of these 'paradigms' while being able to control for many historical and path-dependent variables that would clearly complicate the analytical picture if we would look, for example, only at the East Asian region over the whole time period (from the 1960s until now); inevitably this is the first illustrative step of a broader analysis that can be done based on this framework. We believe that this discussion is also relevant for Latin America given its developmenatlist and Washington-Consensus-based policy periods (for comparisons of Eastern Europe and Latin America, see Karo \& Kattel, 2010b; Kattel \& Primi, 2012).
} 
appropriate outcomes such as sustainable economic development and welfare (based on values such as legitimacy, accountability, compliance, consent). In essence, literature on development refers to this when discussing the capacity of the Government to implement theoretically sound or ideal-type policies (for a broader critical discussion, see Grindle, 1996 and 2010). It can also be viewed as the legitimacy and extent of Government involvement in a policy area, or the legitimacy (external and selfcreated) to intervene in private-sector activities through different means available to public authorities. This concept can be unpacked by distinguishing two subsidiary concepts that are both preconditions for state capacity. Policy capacity refers to the ability to make intelligent policy choices (based on values such as coherence, credibility, decisiveness, resoluteness). In the context of development, policy capacity refers to the ability of the political system to decide or compromise on the best approach to technological and economic development, or to distinguish between what is 'desirable' and what is 'feasible' through the processes of policy debate and interest coordination (both within bureaucracy and political institutions and between public and private actors). The substance of policy capacity is dependent on the third concept, administrative capacity, which refers to effective resource management (based on values such as economy, efficiency, responsibility, probity, equity) and to the ability of the political system to use its resources for implementing the policy choices that have been made. Further, administrative and policy capacity are interdependent as the institutional memory of a political system is stocked in both levels. In what follows we will mainly talk about policy and administrative capacity under the joint headline of policy capacity. We are interested in how this capacity evolves; however, we assume that these three levels of capacity are often closely interlinked and indeed even difficult to separate from each other.

To integrate these concepts of capacity and development policy literature, we can also dissect these concepts into macro, meso and micro levels. Thus, on macro level we can discuss both external and internal economic and political variables affecting development policy trajectories and how the role of the state in development is perceived and positioned (e.g., different external economic and political constraints, domestic political and legal system, dominant development visions); on meso level, we can concentrate on institutional interactions and coordination mechanisms both within the politico-administrative system (how is this system structured, regulated, managed) and in state-market interactions (what kind of interactions are predominant, e.g., formal $v$ s informal); on micro level we can analyze organizational practices of the bureaucracy and its specific organizations (e.g., personnel, motivation and performance systems). This should also make it clearer that capacity can never be a static and universal concept, but is dependent on the context (of a country, policy field, technological regime) and is also evolutionary.

\section{The key co-evolutionary processes in development}

Based on our framework, it can be seen that the policy capacity is dependent on the evolution of many variables and any model of it will necessarily remain 
incomplete, especially if applied to a single region or country. We concentrate here on some of the variables we see as under-theorized in development policy literature.

We argue that the most crucial limitation of this literature is that both public management (as discussed above) and finance (see also Kattel et al., 2009a) remain mostly on the level of assumptions. That is, most development theories assume that public-management structures and financial institutions work in a specific way and thus can be treated as (mostly) exogenous factors in development proper (notwithstanding whether the latter is unleashed via technological or competitive pressures or via some sort of combination of both). In other words, even strictly evolutionary theories - and notwithstanding Schumpeter's original emphasis on finance in processes of development and innovation (1912, pp. 189-207 and 1939, 109-129) tend to view financial institutions and especially public-management practices as non-evolutionary in nature, or evolutionary only in as far as these react to changes in institutions, or technology, or both. We might say that even evolutionary economic theory treats financial institutions and public-management practices as quasi-evolutionary. ${ }^{4}$

Given these limitations, we propose that we can make better sense how development policies and private-sector dynamism co-evolve (forming different types of policy capacity) by looking at three interrelated complexes of policy arenas and 'choices', each fundamentally evolutionary in nature: policy choices on understanding the nature and sources of technical change and innovation; policy choices on the ways of financing economic growth, in particular technical change; and third, policy choices on the nature of public management to deliver and implement both previous sets of policy choices. ${ }^{5}$ We use the term 'policy choices' due to the lack of a better word; in fact, all of these choices take place over periods of time in often 'messy' political-historical contexts where clear-cut decisions rarely pose themselves and become clearer only in hindsight. These choices go back to political, economic and ideological factors characterizing specific time periods, regions, and economies; and are characterized by long-term processes (via creating legacies and path dependencies), but also by punctuations (such as crises) that lead to important changes in the policy trajectories. The interactions between these policy choices and eventual outcomes(in terms of institutional characteristics of development policy, and its feedback and learning systems on different levels, etc.) lead to evolutionary changes in policy capacity: some ideas (development strategies/models) and ways for its' coordination (policy-making practices) and implementation (management systems) become dominant over others, also in their organizational forms and

\footnotetext{
${ }^{4}$ In Minsky's writings (e.g., Minksy, 1988) regulators of finance (Government), structure of financial sector and productive sector are locked into co-evolutionary processes and engender different types of interactions that Minsky calls different types of capitalism (commercial capitalism, finance capitalism, managerial capitalism and managed money capitalism) that also correspond to different historical periods.

${ }^{5}$ Methodologically, our analysis follows the Schumpeterian socioeconomic co-evolutionary analysis, as summarized in Andersen (2012).
} 
norms; this creates path dependencies and feedback mechanisms that in turn feed into policy learning and evaluation. The impact of these choices and their co-evolutionary results (or, assessments of policy effectiveness and capacities) are revealed in private sector dynamism, or performance.Thus, for the analysis of development policies, not the exact policy choices per se but the evolutionary processes resulting from these choices are more important as the former can be often only conceptually delineated. We can provide in each of the policy complexes a snapshot view of possible policy options (or alternative paths) and respective evolutionary processes often associated with these choices.

\section{The nature and sources of technical change}

One of the fundamental issues of development is the understanding of what is the most sustainable way of creating and developing technological capabilities. This is partly related to understanding the dynamics of technological developments, such as the implications of different technological paradigms on production and innovation systems (see Ernst, 2009; Perez, 2002; Yeung, 2013). Partly, it is also an ideological question conditioned by politico-economic traditions and context (including current levels of development, political constraints, and external political and economic pressures). The most robust options can be characterized by two extremes: technological development based on foreign-investment-led processes vs domestic upgrading processes. The former assumes technical change will happen through spill-overs and similar mechanisms (from transfer of knowledge, technology, etc.); the latter assumes the importance of developing and nurturing domestic valuechains with a constant eye on building capabilities for technological upgrading within domestic companies. In many ways, however, the choices about the nature of technical change come down to understanding what competition does in an economy. One way is to understand competition as the main driver of innovation and technical change, and thus competition creates efficiencies in the economy. The other, almost opposing view is to understand technical change as asymmetric (benefits and profits bestowed on innovators are not proportional with other market actors), which leads to imperfect competition but also growth; thus competition is about bringing forth market inefficiencies in the form of new products, services, knowledge, etc. (see Kattel et al., 2009a; Burlamaqui, 2006). These assumptions obviously lead to a widely differing role for Government involvement per se, but also in more specific policy choices in such areas as intellectual property rights, trade regulations, support for universities, vocational training and so forth. In our context what is important is that the array of these choices depends on existing institutional patterns and leads to evolutionary processes in economic structure and specialization, and that feeds crucially into the financial system or how the financing of technological change is structured, but also into public management or how the different policy choices are implemented. And, of course, also vice versa: choices on financial institutions and public-management practices feed into choices on technology and innovation policies. 


\section{Financing technical change}

An equally important factor is the question of how to finance growth and investments in technological development. Here, again, we have alternative views that are conditioned and influenced by the understanding of the nature and sources of technical change, but also technological trajectories, and other political and economic concerns (from international relations to national politics). In short, choices or alternatives about financing of growth are about answering a seemingly simple question: where does the money come from that can be invested into technological upgrading (new machinery and factories, product development, marketing innovation, hiring engineers). While the answer to this question is about the nature of financial systems and regulations to deal with systemic fragilities, it also boils down to two extremes: foreign vs domestic savings. Particularly in the development context this is often a fundamental policy choice, whether to rely on foreign investments, aid and borrowing, or whether to mobilize domestic savings and to opt for an integrated central-bank-based approach (Kregel, 2004). Development literature, especially in its early incarnation during the 1950s, has brought out ample strengths and weaknesses for both choices for financing technological change (for an overview, see Kattel et al., 2009a). A foreign-savings-based strategy of development and growth is often prone to two problems: reversal of flows that plunges economies into deep crisis, and conflicts between the interests of foreign investors and domestic developmental needs. At the same time, with globalization of finance, foreign savings are often readily at hand. Domestic savings and an integrated central-bank approach similarly runs a risk of leading to a vicious circle of mistrust and mismanagement of expectations in the form of high inflation (as the central bank finances Government spending) and dependency on foreign earnings to pay for goods of vital importance (from energy to technology) (Kregel \& Burlamaqui, 2005 and 2006). However, the choices of financing of growth run obviously deeper than a simple foreign vs domestic juxtaposition: e.g., capital controls, exchange-rate management, presence of foreign banks and/or public (developmental) banks, organization of financial bureaucracy, sector-specific lending all offer a variety of areas where Governments make decisions on the financing of growth. These choices obviously have various theoretical and ideological backgrounds; these in turn change strongly over time. What is key in our context is that all of these choices depend again on existing institutional patterns (including legacies, traditions, interests, skills) and lead to manifold evolutionary processes in economic policies, structure and specialization.

\section{The nature of public management}

Choices on public-management systems tend to be both more long-term and historical (or with stronger path-dependencies), and much less clear-cut. While fundamental changes in public management are relatively rare (in the sense that for instance what is a ministry is radically redefined or the overall structure of governance is centrally re-drawn), incremental changes are seemingly permanent (see Pollitt, 2008). However, there are few dimensions where choices can be brought 
out with relative clarity: decisions about public-sector recruitment practices (whether classic Weberian career or more open and flexible systems); decisions on coordination practices (whether these are based on hierarchical means, networks or market-like relations); decisions about the level of centralization or decentralization in public management (both in organizational structure and allocation of tasks); decisions about the levels of autonomy in public-sector organizations (both in substantive policy choices and selection of administrative means) (see Pollitt \& Bouckaert, 2011). These choices generate public-management systems with specific organizational interactions, coordination and access pathways (see also Verhoest \& Bouckaert, 2005); these systems in turn provide the implementation context for the above-described policy choices on financing and steering technical change. However, the public-management system is also where technical and other skills are located and where day-to-day interaction with policy makers, entrepreneurs and others take place. In essence, the public-management system is, then, fundamental to the way policies of financing and sustaining technical change are devised, implemented and evaluated.

\section{CO-EVOLUTIONARY PROCESSES AND POLICY CAPACITY IN EAST ASIA AND EASTERN EUROPE}

Our contention is that these key evolving policy arenas, or policy choices, are tightly interlinked and interactions between these arenas generate specific forms of policy capacity that lead to (or try to create) specific paths and types of economic development and technological processes in the private sector. Obviously, foreigninvestment-led and -financed development policy ideally requires and eventually evolves towards a different set of public-sector skills, coordination practices, decision-making structures and means of assessing performance and accountability than development policy based on building domestic value chains, either financed by foreign or domestic savings. In addition, political and policy institutions have their own internal development paths and interests beyond the confines of development policies/strategies (these stem from broader ideological, historical, and other reasons) and may affect the evolution of these strategies as well. Thus, these arenas have almost an infinite number of possible interactions and the cases of East Asian developmental state (especially as witnesses in the Republic of Korea and the Republic of China - Taiwan) and the Eastern European transition period (especially in countries that have moved from the socialist economy to full members of the European Union) highlight probably the most contrasting empirical cases from the recent history (see also Lim (2011), who implicitly argues that these regions can be treated as most different cases for the analysis of development policies).

Indeed, East Asian economies in the 1960s-1980s and Eastern European countries in the 1990s started to pursue its' autonomous development strategies and policies within clearly different techno-economic paradigms (mass production vs ICT-based production paradigm - see Ernst, 2009; Perez, 2002; Soete, 2007), and 
within largely different international policy and ideational contexts (post-WWII developmental, largely protectionist consensus vs Washington-Consensus-based, clearly liberalization-oriented strategy - see Hall, 2003; Wade, 2000 and 2003), relying on different political systems (authoritarian vs liberal democracies), yet wanted to achieve similar development goals: technological upgrading and economic catching-up via export-led growth.

In the following sections we will not describe in detail how the key policy choices of development emerged in these regions as it is relatively well established in the literature how East Asian and Eastern European policies have resulted in almost opposite institutional systems for financing, building and managing technoeconomic systems (we have tried to summarize the key elements - goals, instruments, practices, processes - into Figure 1, see p. 90). What we want to elaborate upon is how these differences led to different forms of policy capacity and technoeconomic performance. Further, we want to show that the reversal or change of these paths and capacities - if desired by political or economic elites, or prescribed by techno-economic changes on a global scale - is inevitably again a 'messy' processes of co-evolutionary change between and spurred by the three (at least) policy arenas and choices we have depicted above.

\section{Policy capacity in the East Asian developmental state}

Despite the more or less pronounced political, ethnical, cultural and economic difference between East Asian economies, we can state at some level of generalization (especially as compared to other regions and time periods) that the developmental state's understanding of how technological and economic development can be sustained was based on the nurturing and development of domestic capabilities. The brief experiences of import-substitution-industrialization and subsequent shift to export-led growth strategies supported by the carefully state-steered use of mostly foreign financing (foreign loans) for national development can be interpreted as a pragmatic and incremental compromise in trying to sustain complementarities between developmental strategies and finance, and to achieve economic development guaranteeing national independence and autonomy from external pressures (see Haggard (1990) for the most detailed comparative analysis; also Amsden, 1989; Haggard, 2004; Whitley, 1999; Wade, 1990).

Given the counter-intuitive character of this development strategy (use of foreign financing and exporting to foreign markets for national political and economic autonomy), it is generally agreed that the policy-making and implementation practices of East Asian economies were highly complex. The key feature of this policy mix was bold prioritization of economic activities with potential increasing returns and feedback linkages to other sectors of the economy that was made feasible by the authoritarian political practices allowing reforms to de-privilege or control existing wealth-based elites (also labor and business) and reaching to sectorspecificity from macroeconomic policies (in the form of preferential interest rates and loans to targeted industries, etc.) through to industrial policies (in the form of 
Figure 1: Policy capacity for development in East Asia and Eastern Europe

\section{Financing of Technical Change}

East Asia: domestic public banks; low level or managed role for FDI; preferential sectoral interest rates and controlled access to foreign borrowing.

Eastern Europe: foreign savings (high openness to FDI and loans), rapid internationalization of banks, highly horizontal, full convertibility; high Euroization of borrowing.

\section{Nature of Technological Change}

East Asia: domestic linkages and valuechains as key processes of change; public technology transfer via licensing, reverse engineering, low IPR protection, domesticmarket protection, managing competition, state-owned companies; high productivity increases, specialization into increasing returns industries and skills.

Eastern Europe: FDI as key driver of technological change; emphasis on macro-economic stability, WTO-type rules, no competition management; export and high-tech enclaves; low productivity, dominance on service sector (real-estate, tourism, retail, etc)

\section{Nature of Public Management}

East Asia: insulated and technically skilled Weberian bureaucracies, access to high-level politics; managing processes (private-sector skill development) rather than outcomes; strong coordination of policy design and implementation; conscious creation of market inefficiencies; strong learning via state-market interactions, informal ties.

Eastern Europe: insulated and specialized agencies following private sector type management principles (new public management) and oriented towards managerial and performance efficiency (bang-for-the-buck); highly fragmented organization; weak coordination and design; weak learning as state-market relations based on distrust and distance.

\section{Evolution of Policy Capacity in Economic Policy}

East Asia: strong complementarities between finance, technology policy and public management; continuous policy learning; conflicts subsumed under developmentalist goals and highly interlinked or coupled government-business relationships.

Eastern Europe: strong mismatch between finance (oriented towards service sector), export sector (outsourcing), high-tech sector and public management (output efficiency); conflicts erode legitimacy and trust in government-business relationships.

Source: Authors based on varied sources. For East Asia, see for example, Amsden (1989), Amsden and Chu (2003), Cheng et al. (1998), Chou (1995), Haggard (1990 and 2004), Haggard et al. (1994), Johnson (1982), Lee and Haggard (1995), Lim (2012 and 2011), Nam and Lee (1995), Wade (1990; 2000). For Eastern Europe, see Becker and Weissebacher (2007), Bohle and Greskovits (2009), Bouckaert et al. (2008), Duman and Kurekova (2012), Gabor (2012), Karo (2011), Karo and Kattel (2010a), Karo and Looga (forthcoming), Kattel (2010), Kattel et al. (2009b), Lande and Myant (2007), Mrak et al. (2004), Myant and Drahokoupil (2010), Nemec (2008), Piech and Radosevic (2006), Radosevic (2009 and 1998), Suurna and Kattel (2010), Török (2007). 
foreign technology licensing, local content requirements, state-owned enterprises, Government research institutes, etc.). While the ultimate goal, or performance criteria, of industrialization and development policies was external competitiveness or export-performance, the domestic markets were insulated behind protective tariffs and other administrative means, which made it possible to use the domestic market as experimenting and learning ground, both for policy-makers to design general upgrading strategies and for firms and industries for developing specific capabilities.

Institutionally, design and implementation of this policy mix required bureaucracy that was not only highly skilled (and often also sealed off from the general bureaucratic processes covering other policy fields; for comparative analysis, see Cheng et al., 1998), but also flexible (in terms of incentives and policy space - e.g., the use of 'administrative guidance' as explained in Johnson, 1982) to in fact use the lessons gained from experimentation and learning. The concept of 'embedded autonomy' (see Evans, 1995) covers the two sides of this context: bureaucratic autonomy from political and generic pressures complemented with close linkages, or embeddedness, to the policy targets (companies, industries). The developmental state typically attempted to retain (managed) competition within the prioritized sectors through such measures as 'sunset clauses' and performance targets (especially related to export success), set both on bureaucracy (i.e., bureaucratic effectiveness was assesses through its success in fostering private sector dynamism) and the private sector (i.e., ability to export was one of the key criteria for any Government support). Such a policy intervention model was assumed to engender dynamic inefficiencies (in essence to create market 'failures' or 'getting the prices wrong') in the form of faster productivity growth in prioritized sectors and diffusing through supplier and other networks into wider economy as enforced learning processes (and also higher wages). Crucially, such inefficiencies brought about 'feedback' loops into the political governance of the economy as previous policy choices - in terms of the role of the state in development and its' finance and more detailed selections of instruments and practices - were regarded as validated, and thus further priorities-based policy action became strongly legitimized. Thus, the interlinkages and tight inter-dependence between politics, policy and business became self-legitimizing tools for the development model, and the political system in particular. Of course, more detailed analysis can reveal important differences in this general trajectory between different countries.

In Korea, these institutional interactions have been probably most visible as political actors actively intervened in daily policy-making (in fact affecting the levels of bureaucratic autonomy from politics), the industrial policy space and scope was very broad (industrial policy goals resided over macroeconomic policy), and the state had very close ties with very few business actors (i.e., chaebols). As a result, bureaucracy became relatively centralized - in terms of political control of it, but also in task accumulation - and subsequently more generalist in its expertise and orientation. The blurring of political and bureaucratic tasks diffused political and administrative autonomy and made policy rather fluid (or prone to reversals, con- 
stant reforms in the development path). In Taiwan, the importance of maintaining macroeconomic stability over industrial policy priorities (related to political elite's past failures to maintain economic stability on mainland China), and more established borders between Government and the private sector (due to ethnic divisions between the rulers and the ruled) reduced both the flexibility/fluidity and the scope of industrial policy, established a more explicit division between political (reigning) and policy-level (ruling) tasks in industrial policy, and created a relatively specialized bureaucracy with both more limited concentration of policy tasks and more concentrated competences (e.g., importance of engineering skills in bureaucracy). Thus, while in the case of Korea the Government and business sector were highly intertwined (from coordination of industrial planning to Government bailouts and policy loans to key businesses to 'descent from heaven' avenues for political and bureaucratic elites - for critical accounts see also Kang, 2002; Gomez 2002), in Taiwan the Government was more distanced from the business sector and the Government has relied on more formalized forms of collaboration with the industry (granting of subsidies, technological licenses, etc via a more transparent or predictable policy process) and on state-led development strategies (e.g., importance of Government research institutes and state owned enterprises for developing new technological capabilities in and for the economy). These differences - we argue are incremental deviations in the general common path of understanding development and were caused by contextual differences, past legacies and how the coevolutionary processes between development strategies, finance and public management played out in specific context; thus, also East Asian policy capacity has been evolutionary and dynamic within this overall path.

\section{Policy capacity in the Eastern European transition}

The analysis and assessment of the Eastern Europe transition over the last two decades is much more fluid and open-ended and we can distinguish two distinct phases. In the early 1990s, the development thinking was centered on Washington Consensus policies and most Eastern European emphasized macro-economic context and left industrial and innovation policies out of policy attention. The general consensus (with some exemptions, notably Slovenia) was that FDI could (or had to) work as a panacea for economic restructuring by bringing technological knowledge, skills, and also finance for development. The view of the role of state and policies became relatively straightforward as macroeconomic stability, liberalization, attraction of FDI could all be achieved via universal regulatory policies. The only active role for the state remained in 'traditional' tasks, such as in education, in which Eastern European economies had been relatively effective also before. As a result, no substantive thinking about economic bureaucracies emerged and policy implementation systems evolved along generic logic of public management reforms, which neglected Weberian hierarchical principles and opted for institution building via emulating Western economies and private sector management principles (see Bouckaert et al., 2008). 
The assessment of this period is highly contradictory, depending on the benchmarks and political/ideological acceptance of alternative development strategies. On the one hand, many Eastern European economies have been highly successful in transforming its economic systems from socialist planning economies to competitive market economies and in receiving massive amounts of FDI. These developments have indeed turned most of the Eastern European industry upside down, replacing almost all capabilities within a very short period of time (see Havlik, 2005). On the other hand, various assessments (summarized in Karo \& Kattel, 2010a; Suurna \& Kattel, 2010; Aidis \& Welter, 2008) bring out major structural vulnerabilities in Eastern European private-sector developments: large parts of export industry have become foreign-owned and tend to be oriented towards relatively simple production, with limited and often no linkages among local suppliers and other market institutions (universities, research institutes, other companies of the sector, or value chain); public research and development institutions have grown increasingly detached from industrial needs as applied and industry-oriented research has been neglected by the higher education systems. Also, a massive influx of foreign funding created real estate and other asset bubbles during the 2000s, skewing the economic structure towards non-technological and non-exporting sectors (see Kattel, 2010; Havlik, 2005). As a result, the private sectors tend to be fragmented into groups with diverging interests and views of development: exporters tend to need cheap labor and low taxes; the service sectors tend to need easier access to finance and low taxes.

During the second period starting in late 1990s, industrial and innovation policy concerns started to gradually take a more central position in economic development debates. This shift was the outcome of the European Union's structural assistance policies towards potential member states and led to relatively universal policy approach across the region emphasizing high-technology policies and emulation of developed economies (Kattel \& Suurna, 2010; Piech \& Radosevic, 2006). As this thinking was externally imposed, there was no significant change in the political perceptions of how development and its financing should be achieved (i.e., via FDI), at least among political elites, financial bureaucracy, but also among most economic elites who tended to lack capabilities for high-tech production and development. Industrial and innovation policy became a competing, but politically inferior, view as Eastern European introduced vast lists of EU financed instruments (mostly geared at high-tech) and institutions for the implementation of these policies.

The key focus of institutional design of this new policy arena was on technocratic and managerial efficiency, or performance (e.g., distribution of grants and subsidies via open market competition among applicants without ex ante sectoral or other prioritization; cost efficiency via standardization and unification of instruments, etc.) that could be most easily developed in newly created innovation agencies functioning in parallel to existing policy institutions. This efficiency-orientated institution building was based on the view that the state and the market are parallel and not complementary institutions. That is, the logic of development still perceived market signals (via FDI) as the main engine of development; the role of 
the state (and the new agencies and instruments) was to mimic more developed markets and speed-up the institutional convergence (by also copying or emulating policy instruments of more developed economies). Thus, bureaucratic organizations - mostly dealing with policy implementation - paralleled dominant paradigms in the private sector (in terms of management skills, processes, etc.). This marketized and contractualized the relationship both between politics and bureaucracy and also Government and business. For example, informal administrativeguidance-type ties between different stakeholders have almost never emerged, or are interpreted as examples of corruption, and the system has been built on $e x$ ante formalization of policy-making and most notably implementation processes (via performance contracts, etc).

If we see policy capacity as co-evolutionary, we see that in Eastern Europe the parallel existence of two views of development - the dominant view of sustaining and financing development via FDI and gradually emerging view of supporting development also by firm- and industry-level policies - has not created a common logic of what kind of policy-making strategies and implementation skills are needed. Industrial and innovation policy - mostly taking the form of designing and granting subsidies - requires different sets of organizations, skills and practices than designing and enforcing regulatory policies of liberalization. As these two models have - at least politically - existed in parallel, there has been no need for substantive coordination that would bring about inherent conflicts and contradictions in policy institutions. The only place where this contradiction is revealed is in the feedback systems between fragmented policies and its' impact on the dynamism of the equally fragmented private sector. These challenges tend to be defined problems of policy coordination and the solutions are usually sought from developing trustbased and more collaborative/networked policy settings. In this context, the critical analysts who try to look behind macro-level performance indicators tend to argue that Eastern European industrial and innovation policy is contributing relatively little to private sector developments, partly because of the parallel dynamics of FDI-based policy, but partly because the existing technocratic and one-size fits-alltype public management of industrial and innovation policies has made it especially difficult to provide policy instruments that fit either national, or industry-, or firm-level needs. At the same time, it has become increasingly difficult to build better ties between industry on the one hand and politics and bureaucracy on the other, as the former has little to contribute to the relatively technocratic focus of policy-making and the latter collect their legitimacy from the international policy arenas through policy transfer and international benchmarking. Such mismatch feeds mistrust between the state and market actors as state interventions, also into high-technology fields, are seen as zero-sum games, and often are.

\section{Different forms of policy capacity in East Asian and Eastern Europe}

Our argument is that the above-depicted co-evolutionary processes have led to different forms of policy capacities that are also reflected in the institutional char- 
acteristics of respective public management systems. Table 1 summarizes the key characteristics of these different forms of policy capacities. In these two regional cases the institutions of public management are able to achieve very different things in development-policy context: substantive effectiveness vs technocratic efficiency.

Further, these differences in capacities further illuminate what kinds of institutional settings became available for feedback and learning systems between public and private sector. In East Asia, the way technological change was understood and also financed provided also policy space to build bureaucratic structure that, while formally looking highly Weberian, had also important formal and informal characteristics that fostered embedded Government-business collaborative networks that were the basis of the East Asian development state and its legitimacy. In Eastern Europe, an almost opposite view of development and how to finance it took prominence and significantly reduced the policy space for the Governments to lead or coordinate technological and development processes in the private sector. Government activities and investment into structural change tend to have low returns because of the fragmented evolution of private-sector capabilities and also fragmented and mistrustful learning linkages between public and private sector. The key feedback loop in policy-making is formed by emphasizing avoidance of Government capture and failure in the form of monopolistic markets and emergence of business models based on Government support.

Table 1: Two types of policy capacity in development policy

\begin{tabular}{|c|c|c|}
\hline & East Asian development & Eastern European transition \\
\hline $\begin{array}{l}\text { Macro-level } \\
\text { characteristics of } \\
\text { policy institutions }\end{array}$ & $\begin{array}{l}\text { Partially representative and } \\
\text { autonomous institutions: } \\
\text { - selective access to state institu- } \\
\text { tions and insulated bureaucracy }\end{array}$ & $\begin{array}{l}\text { Representative institutions: } \\
\text { - high transparency and access to } \\
\text { state institutions; stakeholder equal- } \\
\text { ity; public accountability as control } \\
\text { mechanisms }\end{array}$ \\
\hline $\begin{array}{l}\text { Institutions of } \\
\text { the policy design } \\
\text { processes }\end{array}$ & $\begin{array}{l}\text { Distinction between political } \\
\text { and bureaucratic policy design: } \\
\text { - political strategy-building as } \\
\text { ideological vision-setting } \\
\text { - bureaucratic policy design as } \\
\text { plan-rational accommodation } \\
\text { and interpretation of ideological } \\
\text { visions } \\
\text { - state-led interactions with mar- } \\
\text { ket actors for feedback }\end{array}$ & $\begin{array}{l}\text { Blending of political and } \\
\text { bureaucratic policy design: } \\
\text { - technocratic strategy-building } \\
\text { based on globally converging ideas } \\
\text { and best-practices } \\
\text { - strategies and visions through inter- } \\
\text { est/market competition } \\
\text { - parallelism between state and mar- } \\
\text { ket institutions reducing feedback }\end{array}$ \\
\hline $\begin{array}{l}\text { Institutions } \\
\text { of policy } \\
\text { implementation } \\
\text { processes }\end{array}$ & $\begin{array}{l}\text { Bureaucratic policy } \\
\text { institutions } \\
\text { - centralized development agen- } \\
\text { cies based on Weberian prin- } \\
\text { ciples } \\
\text { - consolidation of industrialization- } \\
\text { related policy domains and tasks } \\
\text { - policy space for both formal and } \\
\text { informal interactions }\end{array}$ & $\begin{array}{l}\text { Managerial policy institutions } \\
\text { - innovation agencies based on pri- } \\
\text { vate-sector managerial principles } \\
\text { - specialization of policy institutions } \\
\text { (both in terms of domains and } \\
\text { tasks) } \\
\text { - formalization and contractualization } \\
\text { of interactions in policy implementa- } \\
\text { tion }\end{array}$ \\
\hline
\end{tabular}




\begin{tabular}{|c|c|c|}
\hline $\begin{array}{l}\text { Key policy } \\
\text { delivery } \\
\text { institutions }\end{array}$ & $\begin{array}{l}\text { Mix of formal and informal } \\
\text { tools } \\
\text { - regulations and subsidies for } \\
\text { selective steering and protection } \\
\text { of local market actors } \\
\text { - state entrepreneurship - state } \\
\text { R\&D institutions, development- } \\
\text { oriented state-owned enterpises } \\
\text { - administrative guidance }\end{array}$ & $\begin{array}{l}\text { Formalization of policy delivery } \\
\text { - regulations - creating framework } \\
\text { conditions and setting the scene for } \\
\text { market competition and collabora- } \\
\text { tion } \\
\text { - subsidies - main subsidies for R\&D } \\
\text { (both private and academic), in- } \\
\text { creasingly for collaborative R\&D (be- } \\
\text { tween academic and market actors) }\end{array}$ \\
\hline $\begin{array}{l}\text { Key policy } \\
\text { evaluation and } \\
\text { performance } \\
\text { criteria }\end{array}$ & $\begin{array}{l}\text { Process improvements } \\
\text { - in export, R\&D capabilities etc. } \\
\text { - substantive bureaucratic ac- } \\
\text { countability (internal) } \\
\text { - private-sector performance as } \\
\text { part of policy performance }\end{array}$ & $\begin{array}{l}\text { Policy outputs and outcomes } \\
\text { - emphasis on external accountability } \\
\text { through ideal-type ex-ante deter- } \\
\text { mined formal outputs and outcomes } \\
\text { (for example, patent statistics) }\end{array}$ \\
\hline $\begin{array}{l}\text { Types of } \\
\text { state-market } \\
\text { interactions }\end{array}$ & $\begin{array}{l}\text { State-led networks } \\
\text { - basic normative goals and di- } \\
\text { rection determined by political } \\
\text { institutions }\end{array}$ & $\begin{array}{l}\text { Self-organizing networks } \\
\text { - competitions between local search } \\
\text { networks and external pressures }\end{array}$ \\
\hline $\begin{array}{l}\text { Private sector } \\
\text { dynamics }\end{array}$ & $\begin{array}{l}\text { Strong evolution of linkages } \\
\text { throughout value-chains } \\
\text { - strong linkages among export- } \\
\text { ers, supplier networks and mar- } \\
\text { ket institutions } \\
\text { - linkages ensure effective public } \\
\text { interventions and legitimize the } \\
\text { latter in the process }\end{array}$ & $\begin{array}{l}\text { Weak linkages between and with- } \\
\text { in foreign and domestic } \\
\text { - fragmented private sector with } \\
\text { diverging interest and mistrust to- } \\
\text { wards the public sector } \\
\text { - public-sector interventions often } \\
\text { do not complement private-sector } \\
\text { capabilities, further de-legitimizing } \\
\text { state activities }\end{array}$ \\
\hline
\end{tabular}

Source: Authors.

\section{CONCLUSIONS}

In this paper we have looked at policy capacity not as a continuum of abilities, but as a mode of making policy. We have argued that the specific forms of policy capacity, at least in the context of development policies, are revealed in the feedback linkages between policy and market actors. Given the specifics of development policy, the institutional foundations of policy capacity stem from key policy choices on understanding the nature and sources of technological change, on financing of technological change, and on the forms of public management. Using the case studies of East Asia's developmental state and Eastern European transition, we have tried to show how these three policy choices have co-evolved and created specific feedback linkages and resulted in different forms of policy capacity.

To summarize, in East Asian developmental state the mix of strategies for technological change, its financing systems and the systems for its management created a self-reinforcing logic in policy capacity: policy successes legitimised the 
further role for policy and its institutions. In Eastern Europe, the mix of technological change strategies, its financing and the systems for its management have created an almost a perverse logic in policy capacity whereby policy successes are almost impossible to measure in terms of public-sector activities and therefore policies re-create a continued emphasis on avoiding Government capture and failure, instead of focusing on substantive issues. Thus, in these two cases, institutions of public management are able to achieve very different things for development: substantive effectiveness vs technocratic efficiency. The differences in state-market interactions or feedback systems - developmentalist embeddedness vs neoliberal distance - reflect these differences in the broader context of economic development.

While our analysis has looked at two different regions in two different time periods - to depict the co-evolution of different policy choices and how these lead to variety of forms of capacity - our theoretical claim is that there is no rule of thumb, or models of policy capacity that could be taken as benchmarks, or sources of direct policy emulation. Rather, policy capacity is always co-evolutionary; institutionally it builds on the choices of development strategy, its financing, and its management; and its impact on development results from private sector dynamism; and private sector dynamism also leads into further evolutions in policy capacity, both in its impact on development and in its institutional form. Research on development policies should take these co-evolutionary dynamics explicitly into account.

While development policy scholars tend accept that WTO rules have significantly reduced the policy space for nation-states to adopt developmental state's strategies for technological change and its financing (given the global IPR regulations, rules on financial liberalization, etc.), at the same time we have very limited systematic acknowledgement of what happens (or has happened) with policy implementation and public management systems. In the context of East Asia, we see that some scholars argue that developmental state model does not work well in the new high-technology industries (see Wong, 2011; Yeung, 2013). Others see that given the reduced policy space, effective policy implementation may become even more crucial, or that also the developmental state bureaucracies have been able to evolve and maintain its role in East Asian development (see Amsden \& Chu, 2003; Breznitz, 2007; Lim, 2011; Thurbon, 2003; Thurborn \& Weiss, 2006). We need a more systematic and theoretical understanding of the institutional characteristics of policy implementation systems, and how these affect policy ideas, implementation and learning.

In the case of Eastern European economies, the comprehension of the role of policy implementation in the overall path of development is even more rudimentary, both in academia and policy circles. We have shown that Eastern European countries sought in the 1990 s to actively de-couple economic interests from presumably weaker and less developed domestic political structures. Given the polarized assessments of this strategy, we see increasing discussions about the need to re-couple technological and industrial processes with domestic political and policy institutions. This is perhaps best exemplified by initiatives, led by European Com- 
mission, in the region to establish smart specialization strategies and policies that should concentrate policy efforts into few key sectors/activities and be based on what is called 'entrepreneurial discovery' where Governments and businesses try to jointly distinguish the most promising industrial and academic sectors with domestic complementarities and potential for international competitiveness and build customized policy priorities and instruments to support the development of these sectors/activities (for original idea, see Foray et al., 2009 and 2011). Given the legacy of de-coupling, we see that building new arenas for more intensive Government-business collaborations may be especially difficult task because it may require rethinking the logic of technological change and its financing (i.e., changing the mindset that FDI from developed economies will automatically 'lift' domestic capabilities), but also ways of managing this revised approach to development policy (i.e., shift from managerial efficiency). Currently, the ideas behind smart specialization seem to concentrate solely on building policy coordination and business-Government ties on the level of setting policy priorities and not much is said about the implementation of these initiatives. Similar arguments about linking public management and development strategies and contextualizing global policy and management ideas in the Latin American context are made in Bresser-Pereira (2007).

Whether certain public management systems make sense for development or not is an important academic and theoretical question, but we believe that in the context of development policy research and its normative goal of influencing development policy practices, we also need understand and study how public management and policy implementation systems co-evolve with development strategies in specific contexts in order to offer more hands-on and feasible policy recommendations.

\section{REFERENCES}

Aidis, R. and Welter, F., eds. (2008) The Cutting Edge: Innovation and Entrepreneurship in New Europe, Cheltenham: Edward Elgar.

Amsden, A. (1989) Asia's Next Giant: South Korea and Late Industrialization, Oxford: Oxford University Press.

Amsden, A. and Chu, W. (2003) Beyond Late Development: Taiwan's Upgrading Policies, Cambridge: MIT Press.

Andersen, E.S. (2012) “Schumpeter's Core Works Revisited: Resolved Problems and Remaining Challenges”, Journal of Evolutionary Economics 22: 627-648.

Becker, J. and Weissenbacher, R., eds. (2007) Dollarization, Euroization and Financial Instability Central and Eastern European Countries between Stagnation and Financial Crisis?, Marburg: Metropolis.

Bohle, D. and Greskovits, B. (2009) "Varieties of Capitalism and Capitalism "tout court"”, European Journal of Sociology 50: 255-386.

Bouckaert, G. et al., eds. (2008) Public Management Reforms in Central and Eastern Europe, Bratislava: NISPAcee.

Bresser-Pereira, L.C. (2012) “Five models of capitalism”, Brazilian Journal of Political Economy 32(1): 21-32.

Bresser-Pereira, L.C. (2007) “The Structural Public Governance Model”, International Public Management Review 8(1): 16-31. 
Breznitz, D. (2007) Innovation and the State: Political Choices and Strategies for Growth in Israel, Taiwan and Ireland, New Haven: Yale University Press.

Burlamaqui, L. (2006) "How Should Competition Policies and Intellectual Property Issues Interact in a Globalised World? A Schumpeterian Perspective", The Other Canon Foundation and Tallinn University of Technology Working Papers in Technology Governance and Economic Dynamics, 6. Available from www.technologygovernance.eu [accessed 1 May 2013].

Cheng, T.J., Haggard, S. and Kang, D. (1998) "Institutions and Growth in Korea and Taiwan: The Bureaucracy”, Journal of Development Studies 34: 87-111.

Chou, T.C. (1995) “Taiwan”, in S. Haggard and C.H. Lee, eds, Financial Systems and Economic Policy in Developing Countries, Ithaca, NY and London: Cornell University Press, pp. 56-75.

Dore, R. (2000) Stock Market Capitalism: Welfare Capitalism. Japan and Germany vs the Anglo-Saxons, Oxford: Oxford University Press.

Duman, A. and Kurekova, L. (2012) "The Role of State in Development of Socio-Economic Models in Hungary and Slovakia: The Case of Industrial Policy”, Journal of European Public Policy 19(8): 1207-2128.

Ernst, D. (2009) “A New Geography of Knowledge in the Electronics Industry? Asia's Role in Global Innovation Networks", East-West Center Policy Studies 54. Available from: http://www.eastwestcenter.org/fileadmin/stored/pdfs/ps054_2.pdf [accessed 1 May 2013].

Evans, P. (1995) Embedded Autonomy: States and Industrial Transformation, Princeton: Princeton University Press.

Foray, D., David, P. and Hall, B. (2009) "Smart specialisation-the concept”, Knowledge economists policy brief 9. Available: http://ec.europa.eu/invest-in-research/pdf/download_en/kfg_policy_ brief_no9.pdf [accessed 1 May 2013].

Foray, D., David, P. A. and Hall, B. (2011) "Smart Specialisation: From academic idea to political instrument, the surprising career of a concept and the difficulties involved in its implementation", MTEI Working Paper, Ecole Polytechnique Federale de Lausanne.

Gabor, D.V. (2012) “The Road to Financialization in Central and Eastern Europe: The Early Policies and Politics of Stabilizing Transition”, Review of Political Economy 24(2): 227-249.

Gomez, E.T., ed. (2002) Political Business in East Asia, London: Routledge.

Grindle, M. (2010) “Good Enough Governance Revisited”, Development Policy Review 29: 199-221.

Grindle, M. (1996) Challenging the State: Crisis and Innovation in Latin America and Africa, Cambridge: Cambridge University Press.

Haggard, S. (2004) "Institutions and Growth in East Asia”, Studies in Comparative International Development 38(4): 53-81.

Haggard, S. (1990) Pathways from the Periphery: The Politics of Growth in the Newly Industrializing Countries, Ithaca, NY and London: Cornell University Press.

Haggard, S. et al., eds. (1994) Macroeconomic Policy and Adjustment in Korea, 1970-1990, Cambridge: Harvard University Press.

Hall, P.A. and Soskice, D., eds. (2001) Varieties of Capitalism: The Institutional Foundations of Comparative Advantage, Oxford: Oxford University Press.

Hall, R.B. (2003) “The Discoursive Demolition of the Asian Development Model”, International Studies Quarterly 47: 71-99.

Havlik, P. (2005) "Central and Eastern European Industry in an Enlarged European Union: Restructuring, Specialization and Catching-up”, Économie internationale 102: 107-132.

Hollingsworth, J.R and Boyer, R. (1997) Contemporary Capitalisms: The Embeddedness of Institutions, New York: Cambridge University Press.

Jayasuriya, K. (2005) "Capacity Beyond the Boundary: New Regulatory State, Fragmentation and Relational Capacity", in M. Painter and J. Pierre, eds, Challenges to State Policy Capacity: Global Trends and Comparative Perspectives, Basingstoke: Palgrave Macmillan, pp. 19-37.

Johnson, C. (1982) MITI and the Japanese Miracle: The Growth of Industrial Policy, Stanford: Stanford University Press. 
Kang, D.C. (2002) Crony Capitalism: Corruption and Development in South Korea and the Philippines, Cambridge: Cambridge University Press.

Karo, E. (2012) "Modernizing Governance of Innovation Policy through "Decentralization": A New Fashion or a Threat to State Capacities?”, Innovation: Management, Policy \& Practice 14(4): 495-509.

Karo, E. (2011) "Evolution of Innovation Policy Governance Systems and Policy Capacities in the Baltic States", Journal of Baltic Studies 42(4): 511-536.

Karo, E. and Kattel, R. (2010a) "The Copying Paradox: Why Converging Policies but Diverging Capacities for Development in Eastern European Innovation Systems?”, International Journal of Institutions and Economies 2(2): 167-206.

Karo, E. and Kattel R. (2010b) "Coordination of innovation policies in the catching-up context: A historical perspective on Estonia and Brazil”, International Journal of Technological Learning, Innovation, and Development 3(3): 293-329.

Karo, E. and Looga, L. (forthcoming) "Evolution of Economic Restructuring Policies in Slovenia and Estonia: Competing Views on Institutions and Change in Central and Eastern Europe", Journal of International Relations and Development.

Kattel, R. (2010) "Financial and Economic Crisis in Eastern Europe", Journal of Post-Keynesian Economics 33(1): 41-60.

Kattel, R., Kregel, J.A. and Reinert, E.S. (2009a) "The Relevance of Ragnar Nurkse and Classical Development Economics”, in R. Kattel, J.A. Kregel and E.S. Reinert, eds., Ragnar Nurkse (1907-2007): Classical Development Economics and its Relevance for Today, London: Anthem Press, pp. 1-28.

Kattel, R., Reinert, E.S. and Suurna, M. (2009b) "Industrial Restructuring and Innovation Policy in Central and Eastern Europe since 1990", The Other Canon Foundation and Tallinn University of Technology Working Papers in Technology Governance and Economic Dynamics, 23. Available from www.technologygovernance.eu [accessed 1 May 2013].

Kattel, R. and Primi A. (2012) "The periphery paradox in innovation policy: latin America and Eastern Europe Compared”, in R. Boschi and C.H. Santana, eds, Development and Semi-periphery: Post-neoliberal Trajectories in South America and Central Eastern Europe, London: Anthem Press, pp. 265-304.

Kregel, J.A. (2004) "External Financing for Development and International Financial Instability", G-24 Discussion Paper Series 32. Available from: http://www.unctad.org/en/docs/gdsmdpbg2420048_ en.pdf [accessed 1 May 2013].

Kregel, J.A. and Burlamaqui, L. (2006) "Finance, Competition, Instability, and Development Microfoundations and Financial Scaffolding of the Economy", The Other Canon Foundation and Tallinn University of Technology Working Papers in Technology Governance and Economic Dynamics, 4. Available from: www.technologygovernance.eu [accessed 1 May 2013].

Kregel, J.A. and Burlamaqui, L. (2005) "Innovation, Competition and Financial Vulnerability in Economic Development”, Revista de Economia Política 25(2): 5-22.

Lane, D. and Myant, M., eds. (2007) Varieties of Capitalism in Post-Communist Countries, Studies in Economic Transition Series, New York: Palgrave Macmillan.

Lee, C.H. and Haggard, S. (1995) "Introduction: Issues and Findings", in S. Haggard and C.H. Lee, eds., Financial Systems and Economic Policy in Developing Countries, Ithaca, NY and London: Cornell University Press, pp. 1-30.

Lim, W. (2012) “Chaebol and Industrial Policy in Korea”, Asian Economic Policy Review 7: 69-86.

Lim, W. (2011) “Joint Discovery and Upgrading of Comparative Advantage: Lessons from Korea's Development Experience”, in S. Fradoust, Y. Kim and C. Sepulveda, eds, Postcrisis Growth and Development: A Development Agenda for the G-20, Washington: The World Bank, pp. 173-226.

Minksy, H. (1988) “Schumpeter: Finance and Evolution”, Hyman P. Minsky Archive, Paper 314. Available: http://digitalcommons.bard.edu/hm_archive/314 [accessed 1 May 2013].

Mrak, M., Rojec, M. and Jauregui, C.S., eds. (2004) Slovenia: From Yugoslavia to the European Union, Washington: The World Bank. 
Myant, M. and Drahokoupil, J. (2010) Transition Economies: Political Economy in Russia, Eastern Europe, and Central Asia, New Jersey: Wiley-Blackwell.

Nam, S.W. and Lee, C.H. (1995) "Korea”, in S. Haggard and C.H. Lee, eds, Financial Systems and Economic Policy in Developing Countries, Ithaca, NY and London: Cornell University Press, pp. $31-55$.

Nemec, J. (2008) “Public Management Reforms in CEE: Lessons Learned”, in G. Bouckaert et al., eds., Public Management Reforms in Central and Eastern Europe, Bratislava: NISPAcee, pp. 343-71.

North, D. (1990) "A Transaction Cost Theory of Politics", Journal of Theoretical Politics 2(4): 355$-367$.

Painter, M. and Pierre, J. (2005) "Unpacking Policy Capacity: Issues and Themes”, in M. Painter and J. Pierre, eds., Challenges to State Policy Capacity: Global Trends and Comparative Perspectives, Basingstoke: Palgrave Macmillan, pp. 1-18.

Perez, C. (2002) Technological Revolutions and Financial Capital: The Dynamics of Bubbles and Golden Ages, Cheltenham, UK: Edward Elgar.

Piech, K. and Radosevic, S., eds. (2006) The Knowledge-Based Economy in Central and East European Countries: Countries and Industries in a Process of Change, Basingstoke: Palgrave Macmillan.

Pollitt, C. (2008) Time, Policy, Management: Governing with the Past, Oxford: Oxford University Press.

Pollitt, C. and Bouckaert, G. (2011) Public Management Reform: A Comparative Analysis - New Public Management, Governance, and the Neo-Weberian State, Oxford: Oxford University Press.

Radosevic, S. (2009) "Policies for Promoting Technological Catch Up: Towards a Post-Washington Approach”, International Journal of Institutions and Economies 1(1): 22-51.

Radosevic, S. (1998) "'The Transformation of National Systems of Innovation in Eastern Europe: Between Restructuring and Erosion”, Industrial and Corporate Change 7(1): 77-108.

Schumpeter, J.A. (1912) Theorie der wirtschaftlichen Entwickllung, Berlin: Duncker\&Humblot.

Schumpeter, J.A. (1939) Business Cycles. A Theoretical, Historical, and Statistical Analysis of the Capitalist Process, Volume 1, London and New York: McGraw-Hill.

Soete, L. (2007) "From Industrial to Innovation Policy", Journal of Industry, Competition and Trade 7(3-4): 273-284.

Suurna, M. and Kattel, R. (2010) "Europeanization of Innovation Policy in Central and Eastern Europe”, Science and Public Policy 37(9): 646-664.

Thurbon, E. (2003) "Ideational Inconsistency and Institutional Incapacity: Why Financial Liberalization in South Korea Went Horribly Wrong”, New Political Economy 8(3): 341-361.

Thurbon, E. and Weiss, L. (2006) "Investing in Openness: The Evolution of FDI Strategy in South Korea and Taiwan", New Political Economy 11(1): 1-22.

Török, A. (2007) "Industrial Policy in the New Member Countries of the European Union: A Survey of Patterns and Initiatives since 1990", Journal of Industry, Competition and Trade 7(3-4): 255-271.

Underhill, G.R.D. and Zhang, X. (2012) "The Changing State-Market Condominium in East Asia: Rethinking the Political Underpinnings of Development”, New Political Economy 10(1): 1-24.

Verhoest, K. and Bouckaert, G. (2005) "Machinery of Government and Policy Capacity: The Effects of Specialization and Coordination", in M. Painter and J. Pierre, eds, Challenges to State Policy Capacity: Global Trends and Comparative Perspectives, Basingstoke: Palgrave Macmillan, pp. 92-111.

Wade, R. (2003) "What Strategies are Viable for Developing Countries Today? The World Trade Organization and the Shrinking of Development Space", Crisis States Programme Working Papers Series 1. Available from: http://eprints.lse.ac.uk/28239/ [accessed 1 May 2013].

Wade, R. (2000)" Wheels Within Wheels: Rethinking the Asian Crisis and the Asian Model”, Annual Review of Political Science 3: 85-115.

Wade, R. (1990) Governing the Market: Economic Theory and the Role of Government in East Asian Industrialization, Princeton: Princeton University Press.

Walter, A. and Zhang, X. (2012) East Asian Capitalism: Diversity, Continuity and Change, Oxford: Oxford University Press. 
Whitley, R. (1999) Divergent Capitalisms: The Social Structuring and Change of Business Systems, Oxford: Oxford University Press.

Wilson, W. (1887) “The Study of Administration”, Political Science Quarterly 2(2): 197-222.

Wong, J. (2011) Betting on Biotech: Innovation and the Limits of Asia's Developmental State, Ithaca, NY: Cornell University Press.

Zysman, J. (1983) Governments, Markets, and Growth: Financial Systems and the Politics of Industrial Change, Ithaca, NY: Cornell University Press.

Yeung, H.W. (2013) "Governing the market in a globalizing era: development states, global production networks and inter-firm dynamics in East Asia”, Review of International Political Economy. Available:http://dx.doi.org/10.1080/09692290.2012.756415[accessed 1 May 2013]. 